\title{
Optimization of Process Parameters for Cellulase Production from Bacillus sp. JS14 in Solid Substrate Fermentation Using Response Surface Methodology
}

\author{
Jagdish Singh ${ }^{*}$ and Pawandeep Kaur \\ Department of Biotechnology; Mata Gujri College Fatehgarh Sahib Punjab - 147 002, India
}

\begin{abstract}
The aim of this work was to isolate the potent bacterial strains for the production of cellulose enzyme. A total 30 bacterial isolates showed positive results for the cellulase production but highest enzyme activity was shown by isolate JS 14. From the morphological and biochemical reactions, the isolate was identified as Bacillus sp. Cellulase production was studied by this strain using response surface methodology (RSM). A central composite design (CCD) quadratic response surface was applied to explicate the parameters that significantly affected cellulase production in solid substrate fermentation (SSF). The wheat bran concentration and incubation period were significant factors. The process parameters optimized with response surface methodology was wheat bran concentration $400 \mathrm{~g} / \mathrm{L} ; \mathrm{pH}, 6.5$; temperature, $400 \mathrm{C}$ and incubation period 5 days when inoculum $10 \%$ (1x107 cells/ $\mathrm{ml)}$ was used for cellulase production in SSF. Supplementation of lactose and CMC to the wheat bran medium favored the enzyme formation.
\end{abstract}

Key words: Cellulase, response surface methodology, optimization

\section{INTRODUCTION}

Cellulosic material is the most abundant renewable carbon source in the world. Cellulose may be hydrolyzed using enzymes to produce glucose, which can be used for the production of ethanol, organic acids and other chemicals. Cellulase (E.C 3.2.1.4) refers to a class of enzyme that catalyze the hydrolysis of $1,4 \beta$-D glycosidic linkages in cellulose are mainly produced by fungi, bacteria and protozoans (Beguin and Aubert 1994) and have broad range of industrial and commercial applications (Bhat 2000; Adsul et al. 2007; Kaur et al. 2007). An important obstruction in the exploitation of cellulase is expensive production affecting the overall cost of hydrolysis (Chahal et al. 1992; Duff and Murray 1996; Reczey et al. 1996; Nieves et al. 1998). Considerable progress has been made for high cellulase production by optimization of best possible fermentation conditions for the development of economically feasible bioprocess. Optimization of growth and product conditions by classical methods, which involves the change of one variable at a time, is extremely time consuming and expensive. Combinational interactions of medium components for the production of desired compound are numerous and the optimum processes may be developed using an effective experimental design procedure. Response surface methodology (RSM), which is a collection of statistical techniques for designing experiments,

*Author for correspondence: jagdish122@ rediffmail.com 
building models, evaluating the effects of factors and searching for the optimum conditions, has successfully been used in the optimization of bioprocesses (Dey et al. 2001; Wejse et al. 2003; Kristo et al. 2003; Chen et al. 2005). The objective of this work was to isolate an efficient cellulase producing microorganism and produce the enzyme in SSF.

\section{MATERIALS AND METHODS}

Isolation screening and identification of microorganisms

Cellulase producing bacteria were isolated from the soils, decomposing logs and composts collected from the Fatehgarh Sahib Punjab (India) by the spread plate techniques using CMC agar media. The plates were incubated at $37^{\circ} \mathrm{C}$ for $24 \mathrm{~h}$. To visualize the hydrolysis zone, the plates were flooded with an aqueous solution of $0.1 \%$ Congo red for $15 \mathrm{~min}$ and washed with $1 \mathrm{M} \mathrm{NaCl}$ (Ariffin et al. 2008). To indicate the cellulase activity of the organisms, diameters of clear zone around colonies on CMC agar were measured. Besides the cellulase activity of the selected bacterial isolate in liquid medium. The cellulase activity of each culture was measured by determining the amount of reducing sugar liberated by using a dinitrosalicylic acid (DNS) method (Miller 1959). The bacterial isolates with high enzyme production were identified by means of the morphological and biochemical characterizations. The parameters investigated included colonial morphology, Gram staining, catalase production, starch hydrolysis and nitrate reduction test. The results were compared with Bergey's Manual of
Determinative Bacteria (Buchanan and Gibbons 1974).

Experimental design and optimization of process parameters for cellulase production

A central composite design (CCD) was used to pick the factors that influence cellulase production significantly with software Design expert 8.01. In CCD, the range and the levels of the variables investigated in this study are given in Table 1 . The central values (zero level) chosen for the experimental design were; wheat bran concentration (X1) 35\%; $\mathrm{pH}$ (X2) 6.25; temperatures (X3) $35^{\circ} \mathrm{C}$ and incubation time (X4) 5.5 days. Different combination of variables of wheat bran and $\mathrm{pH}$ was adjusted according to the design (Table 2) in the alkaline soya casein medium. Inoculation was carried with $10 \%\left(1 \times 10^{7}\right.$ cells $/ \mathrm{mL}$ ) inoculum and incubated at various temperature and time combinations, according to RSM design (Table 2). Low and high factor settings were coded as -1 and 1 , the midpoint was coded as 0 . The factor settings of trails that ran along the axes drawn from the middle of the cube through the centers of each face of the tube were coded as 1.414 or -1.414 . The Design expert 8.0.1 software, was used for regression and graphical analyses of the data obtained. The optimal concentrations of the critical medium components were obtained by the ridge analysis and also by analyzing the contour plots. The statistical analysis of the model was performed in the form of analysis of variance (ANOVA). The enzyme was extracted by phosphate buffer $(0.1 \mathrm{M}$ and $\mathrm{pH} 6.5)$ from the solid medium on rotary shaker at $200 \mathrm{rpm}$ by filtration and enzyme activity in filtrate was determined.

Table $\mathbf{1}$ - Factors involved in RSM for optimization of cellulose production.

\begin{tabular}{|c|c|c|c|}
\hline Factors and Codes value $(\mathrm{X})$ & $\begin{array}{ll}\text { Value }(-1) \\
\end{array}$ & Value (0) & $\begin{array}{ll}\text { Value } \quad(+1) \\
\end{array}$ \\
\hline Wheat Bran \% (X1) & 30 & 35 & 40 \\
\hline $\mathrm{pH}(\mathrm{X} 2)$ & 5 & 6.25 & 7.5 \\
\hline Temperature $\left({ }^{\circ} \mathrm{C}\right)(\mathrm{X} 3)$ & 30 & 35 & 40 \\
\hline Incubation Period in days (X4) & 2 & 5.5 & 9 \\
\hline
\end{tabular}

\section{Effect of inoculum size on cellulase production} Inoculum concentration of Bacillus sp. JS14 was varied from $5-20 \%\left(1 \times 10^{7}\right.$ cells $\left./ \mathrm{mL}\right)$ in different batches of $200 \mathrm{~mL}$ of the sterilized alkaline soya casein medium containing what bran $40 \% \mathrm{pH} 6.5$ and Incubation was carried out at $40{ }^{\circ} \mathrm{C}$ for 5 days.
Enzyme was harvested by filtration method and enzyme activities was determined

\section{Determination of cellulase activity}

CMCase activity assay was carried out according to the methods developed by Mandels, (1985). 
Reducing sugar was measured by the DNS method using glucose as the standard (Miller 1959). In this study, one international unit (IU) of enzyme activity was defined as the amount of enzyme that liberated one $\mu \mathrm{mol}$ of glucose per minute under the specified conditions from the appropriate substrate.

\section{RESULTS AND DISCUSSION}

Isolation, screening and identification of cellulase producing microorganisms

Total 30 bacterial isolates when applied the Congo red test, showed positive results with clear zone ranging from 1 to $7 \mathrm{~mm}$ (data not shown). Upon further quantitative determination of cellulose degrading enzyme, all the isolates displayed activity of cellulase with the highest enzyme activity from the isolate JS14. Although the Congo red test was sensitive enough for primary isolation and screening of cellulytic bacteria, but the clear zone width did not indicate the amount of cellulase activity, Krootdilaganandh, (2000) reported that bacterial isolates CMU4-4 grown on CMC agar, exhibited the highest enzyme activity in the liquid medium whereas its clear zone was smaller than other isolates. The isolate JS14 showed white colonies on CMC agar. A microscopic examination of the isolate revealed that it was a Gram positive bacterium and produced enzyme catalase. Furthermore, the JS14 displayed starch and nitrate reduction test. From these morphological and biochemical characterization, the isolate was identified as Bacillus sp.

Optimization of process parameters in SSF by Response surface methodology (RSM) for cellulase production

The concentration of wheat bran (X1 $400 \mathrm{~g} / \mathrm{L}), \mathrm{pH}$ (X2 6.5), temperature $\left(\mathrm{X} 340{ }^{\circ} \mathrm{C}\right)$ and incubation period (X4 5days) in solid substrate were chosen as optimum for cellulase production by SSF. Table 2 shows the design and the results of this experiment.

Table 2 - A central composite designs for cellulase enzyme production using RSM.

\begin{tabular}{|c|c|c|c|c|c|}
\hline \multirow[t]{2}{*}{ S.No } & \multicolumn{4}{|c|}{ Values of factors (X) } & \multirow{2}{*}{$\begin{array}{c}\text { Cellulase activity } \\
\text { (IU/L) }\end{array}$} \\
\hline & $\mathrm{X} 1$ & $\mathrm{X} 2$ & $\mathrm{X} 3$ & $\mathrm{X} 4$ & \\
\hline 1. & 35 & 5.50 & 30 & 5.50 & 540 \\
\hline 2. & 35 & 6.50 & 30 & 9 & 420 \\
\hline 3. & 35 & 7.50 & 35 & 2 & 210 \\
\hline 4. & 40 & 6.50 & 40 & 5 & 2040 \\
\hline 5. & 35 & 5.50 & 40 & 5.50 & 1070 \\
\hline 6. & 35 & 6.50 & 40 & 9 & 520 \\
\hline 7. & 30 & 6.50 & 35 & 2 & 130 \\
\hline 8. & 30 & 6.50 & 30 & 5.50 & 590 \\
\hline 9. & 35 & 7.50 & 40 & 5.50 & 2010 \\
\hline 10. & 40 & 6.50 & 35 & 9 & 460 \\
\hline 11. & 35 & 5.50 & 35 & 9 & 290 \\
\hline 12. & 40 & 5.50 & 35 & 5.50 & 1030 \\
\hline 13. & 30 & 7.50 & 35 & 5.50 & 650 \\
\hline 14. & 35 & 6.50 & 35 & 5.50 & 1330 \\
\hline 15. & 35 & 6.50 & 30 & 2 & 230 \\
\hline 16. & 35 & 6.50 & 35 & 5.50 & 1330 \\
\hline 17. & 35 & 6.50 & 35 & 5.50 & 1330 \\
\hline 18. & 30 & 6.50 & 40 & 5.50 & 1080 \\
\hline 19. & 40 & 6.50 & 35 & 2 & 290 \\
\hline 20. & 35 & 6.50 & 40 & 2 & 250 \\
\hline 21. & 35 & 7.50 & 35 & 9 & 330 \\
\hline 22. & 35 & 6.50 & 35 & 5.50 & 1330 \\
\hline 23. & 30 & 6.50 & 35 & 9 & 280 \\
\hline 24. & 40 & 6.50 & 30 & 5.50 & 1550 \\
\hline 25. & 35 & 7.50 & 30 & 5.50 & 200 \\
\hline 26. & 35 & 5.50 & 35 & 2 & 170 \\
\hline 27. & 35 & 6.50 & 35 & 5.50 & 1330 \\
\hline 28. & 40 & 7.50 & 35 & 5.50 & 1490 \\
\hline 29. & 30 & 5.50 & 35 & 5.50 & 780 \\
\hline 30. & 40 & 7.50 & 33 & 5.45 & 1250 \\
\hline
\end{tabular}


Regression analysis was performed to fit the response function with the experimental data. The statistical significance of the second order model equation was checked by an F-test (ANOVA) and the data were shown in Table 3.The regression model for cellulase production was highly significant $(\mathrm{p}<0.003)$ with a satisfactory value of determination coefficient $(\mathrm{R} 2=0.95)$, indicating that $95 \%$ of the variability in the response could be explained by the second-order model equation given as below:

$\mathrm{y}=284.09494+37.31286 \mathrm{X}_{1}+225.23766 \mathrm{X}_{2} 43.4724$

$3 \mathrm{X}_{3}+790.58161 \mathrm{X}_{4}+28.95995 \mathrm{X}_{1} \mathrm{X}_{2}+0.043204 \mathrm{X}_{1} \mathrm{X}$ ${ }_{3}+0.28792 \mathrm{X}_{1} \mathrm{X}_{4}+64.21602 \mathrm{X}_{2} \mathrm{X}_{3}+0.011021 \mathrm{X}_{2} \mathrm{X}_{4}+$ $1.14198 \mathrm{X}_{3} \mathrm{X}_{4}-2.47136 \mathrm{X}_{1}^{2}-261.78389 \mathrm{X}_{2}^{2}$ where $\mathrm{y}$ is the measured response, and $\mathrm{X} 1, \mathrm{X} 2$, $\mathrm{X} 3$ and $\mathrm{X} 4$ are coded independent variables. The Model F-value of 8.16 implied the model was significant (Table 3 ). There is only a $0.01 \%$ chance that a "Model F-Value" this large could occur due to noise. Values of "Prob > F" less than 0.0500 indicated that the model terms were significant. The "Pred R-Squared" of 0.7664 was as close to the "Adj R-Squared" of 0.7757 as one might normally expect (Table 4). "Adeq Precision" measures the signal to noise ratio. A ratio greater than 4 is desirable. Ratio of 9.309 indicated an adequate signal. This model could be used to navigate the design space.

Table 3 - ANOVA for Response Surface Quadratic Model Analysis of variance table [Partial sum of squares - Type III].

\begin{tabular}{|c|c|c|c|c|c|c|}
\hline Source* & & Sum of Squares & Df & Mean Square & F Value & $P$ value Prob $>$ F \\
\hline Model & & $8.405 \mathrm{E}+006$ & 14 & $6.004 \mathrm{E}+005$ & 8.16 & 0.0001 \\
\hline$X 1$ & & $6.060 \mathrm{E}+005$ & 1 & $6.060 \mathrm{E}+005$ & 8.24 & 0.0117 \\
\hline$X 2$ & & $3.812 \mathrm{E}+005$ & 1 & $3.812 \mathrm{E}+005$ & 5.18 & 0.0379 \\
\hline$X 3$ & & $4.427 \mathrm{E}+005$ & 1 & 4.s427E+005 & 6.02 & 0.0269 \\
\hline$X 4$ & & 67779.73 & 1 & 67779.73 & 0.92 & 0.3523 \\
\hline$X 1$ & $X 2$ & 98643.63 & 1 & 98643.63 & 1.34 & 0.2650 \\
\hline$X 1$ & $X 3$ & 321.72 & 1 & 321.72 & 4.374E-003 & 0.9481 \\
\hline$X 1$ & $X 4$ & 75.80 & 1 & 75.80 & $1.030 \mathrm{E}-003$ & 0.9748 \\
\hline$X 2$ & $X 3$ & $4.225 \mathrm{E}+005$ & 1 & $4.225 \mathrm{E}+005$ & 5.74 & 0.0300 \\
\hline$X 2 X 4$ & & $6.007 \mathrm{E}-003$ & 1 & $6.007 \mathrm{E}-003$ & $8.166 \mathrm{E}-008$ & 0.9998 \\
\hline$X 3 X 4$ & & 450.17 & 1 & 450.17 & $6.120 \mathrm{E}-003$ & 0.9387 \\
\hline$X 1^{2}$ & & 23311.90 & 1 & 23311.90 & 0.32 & 0.5818 \\
\hline$X 2^{2}$ & & $4.621 \mathrm{E}+005$ & 1 & $4.621 \mathrm{E}+005$ & 6.28 & 0.0242 \\
\hline$X 3^{2}$ & & 11264.03 & 1 & 11264.03 & 0.15 & 0.7011 \\
\hline$x_{2}$ & & $5.386 \mathrm{E}+006$ & 1 & $5.386 \mathrm{E}+006$ & 73.22 & $<0.0001$ \\
\hline $\begin{array}{l}X 4^{2} \\
\text { Docidnol }\end{array}$ & & $1.103 E+006$ & 15 & 73559.26 & & \\
\hline Residual & & $1.103 \mathrm{E}+006$ & 11 & $1.003 \mathrm{E}+005$ & & \\
\hline Lack of Fit & & 0.000 & 4 & 0.000 & & \\
\hline $\begin{array}{l}\text { Pure Error } \\
\text { Cor Total }\end{array}$ & & $9.509 \mathrm{E}+006$ & 29 & & & \\
\hline
\end{tabular}

*X1 Concentration of wheat bran $(\%), \mathrm{X} 2 \mathrm{pH}, \mathrm{X} 3$ Temperature $\left({ }^{0} \mathrm{C}\right)$ and $\mathrm{X} 4$ incubation period (days).

Table 4 - ANOVA results for cellulase production obtained from CCD.

\begin{tabular}{ccc}
\hline S.NO & Parametr & Value \\
\hline 1. & Std. Dev & 271.22 \\
$\mathbf{2 .}$ & Mean & 817.00 \\
$\mathbf{3 .}$ & Adj R-Squared & 0.7757 \\
$\mathbf{4 .}$ & C.V. \% & 33.20 \\
5. & R-Squared & 0.8840 \\
$\mathbf{6 .}$ & Pred R-Squared & 0.7664 \\
$\mathbf{7 .}$ & Adeq Precision & 9.309 \\
\hline
\end{tabular}


The $3 \mathrm{D}$ response surface based on the dependent variables such as wheat bran concentration, $\mathrm{pH}$, temperature and incubation period are shown in Figure 1. The canonical analysis revealed that maximum CMCase activity of 2040 IU/L was achieved at wheat bran concentration $400 \mathrm{~g} / \mathrm{L} ; \mathrm{pH}$ 6.5; temperature $40{ }^{\circ} \mathrm{C}$ and incubation period of five days.

\section{Effect of inoculum size on cellulase production} Lower inoculum size requires longer time for the cells to multiply to sufficient number to utilize the substrate and produce enzyme. An increase in the number of cells in the inoculums would ensure a rapid proliferation and biomass synthesis. When inoculum size was increased from 5 to $10 \%$ there was increase in enzyme production but after that the activity was decreased (Fig. 2) due to depletion of nutrients by the enhanced biomass, which resulted dwindle in metabolic activity (Kashyap et al. 2002). A balance between the increasing biomass and accessible nutrient would yield an optimal enzyme production (Ramachandran et al. 2004).
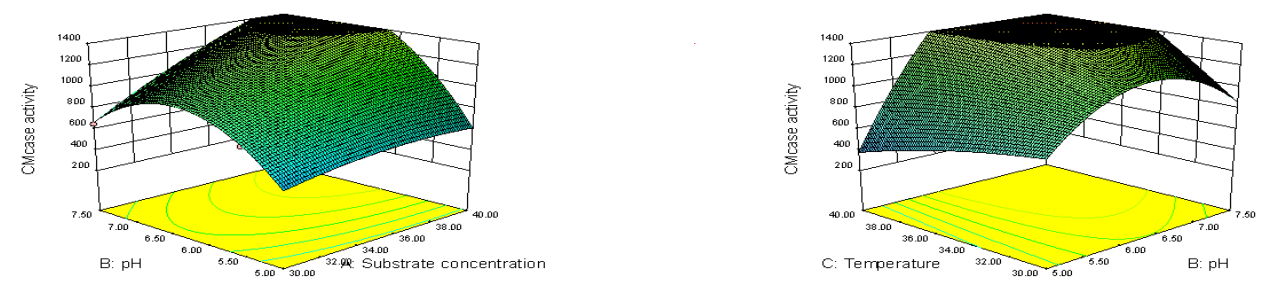

A

\section{B}
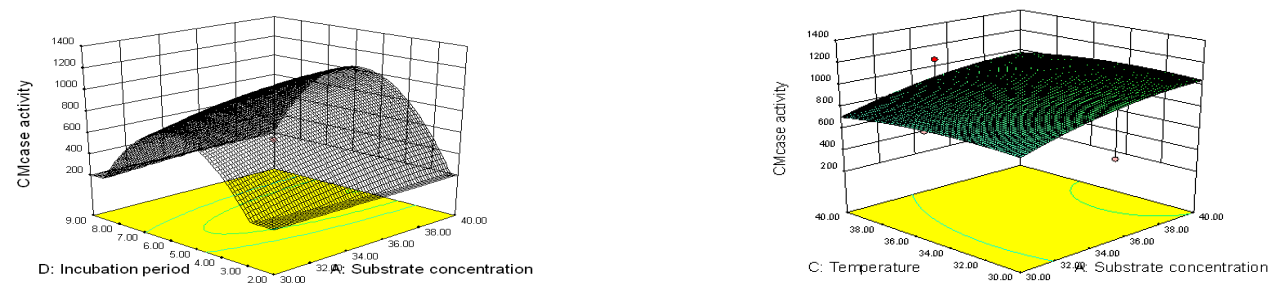

$\mathrm{C}$

D
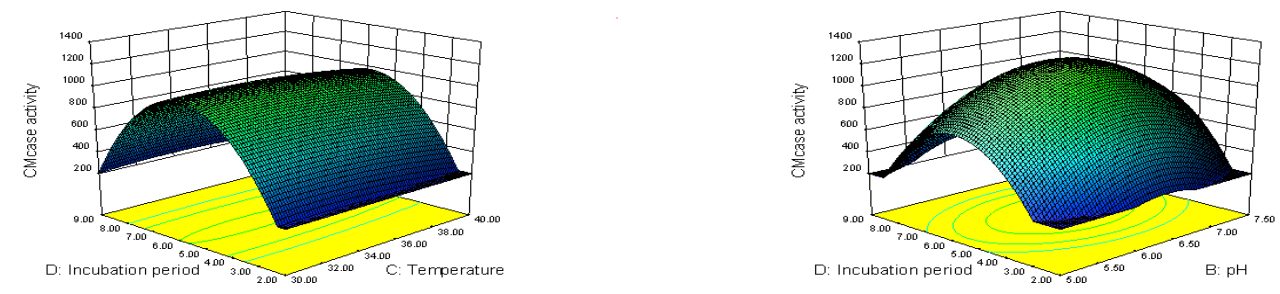

$\mathrm{E}$

$\mathrm{F}$

Figure 1 - Surface plot for the effect of (a) wheat bran and $\mathrm{pH}$ (b) temp and $\mathrm{pH}$ (c) incubation period and substrate conc. and (d) temp and substrate conc. on CMCase activity. 


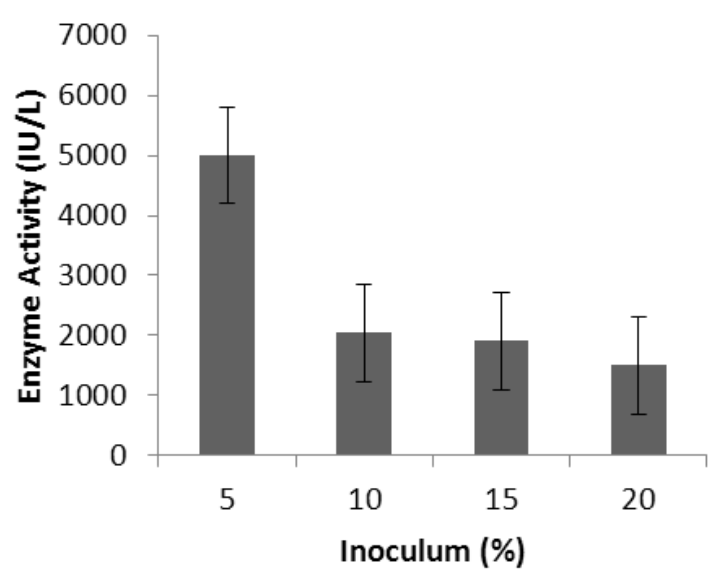

Figure 2 - Effect of inoculum (\%) on enzyme production.

Effect of supplementation of what barn with different carbon sources and ions

Although wheat bran supported the growth of Bacillus sp. JS14 and cellulase production, but it might not supply sufficient nutrients needed by the organism for maximum enzyme production. Hence, the addition of different carbon sources to the medium was conceded to improve the cell growth and enzyme production. The supplementation of wheat straw, rice husk and baggase had little effect on cellulase production, while lactose and carboxy methyl cellulose enhanced enzyme production. Among them, lactose improved the cellulase production the most, which increased $40 \%$ compared to the control (Fig. 3). Lactose was also considered as a good inducer for cellulase production by the Seiboth et al (2005).

The production of cellulase was enhanced by the addition of $\mathrm{NaCl}$ and $\mathrm{MgSO}_{4}$ while EDTA reduced the production (Fig.4).

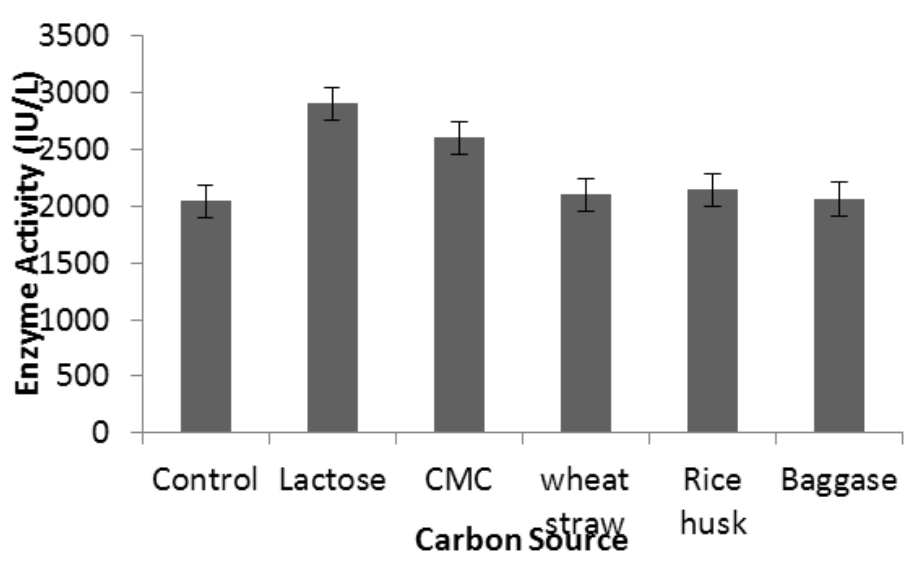

Figure 3 - Effect of different supplement carbon sources on the cellulase production. 


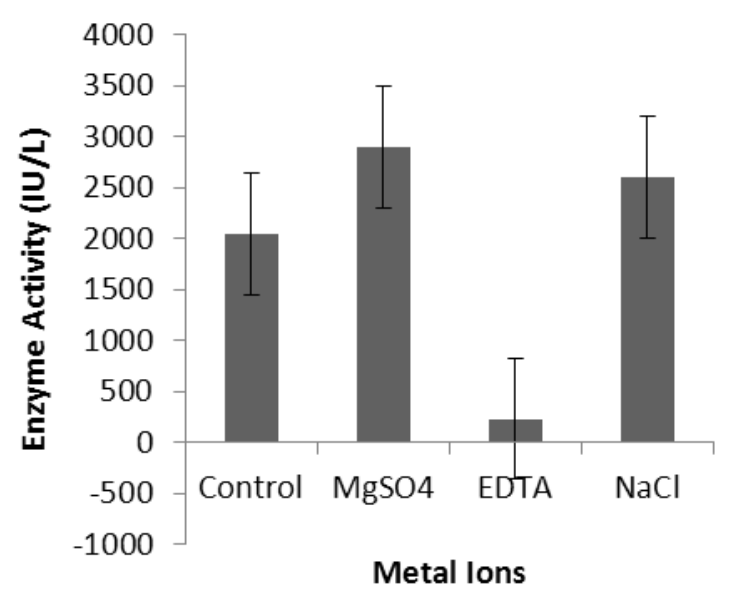

Figure 4 - Effect of different ions on the cellulase production.

\section{REFERENCES}

Adsul MG, Bastawde KB, Varma AJ, Gokhale DV. Strain improvement of Penicillium janthinellum NCIM 1171 for increased cellulaseproduction. Bioresour Technol. 2007; 98: 1467-1473.

Ariffin HN, Abdullah MS, Umikalsom Y, Shirai, Hassan MA. Production of bacterial endoglucanase from pretreated oil palm empty fruit bunch by Bacillus pumilus EB3. J Biosci Bioeng. 2008; 106: 231-236.

Beguin P, Aubert JP. The biological degration of cellulose. FEMS Microbiol Rev. 1994; 13: 25-28.

Bhat MK. Cellulases and related enzymes in biotechnology. Biotechnol Adv. 2000; 18:355-383.

Buchanan RE, Gibbons NE. Bergey's of determinative bacteriology. America: United States of America. 1974; 529-563.

Chahal PS, Chahal DS, Andre G. Cellulase production profile of Trichoderma reesei on different cellulosic substrates at various $\mathrm{pH}$ levels. J Ferment Bioeng. 1992; 74: 126-128.

Chen F, Cai TY, Zhao GH, Liao XJ, Guo LY, Hu XS. Optimizing conditions for the purification of crude octacosanol extract from rice bran wax by molecular distillation analyzed using response surface methodology. J Food Eng. 2005; 70: 47-53.

Dey G, Mitra A. Banerjee R, Maiti BR. Enhanced production of amylase by optimization of nutritional constituents using response surface methodology. Biochem. Eng. J. 2001; 7: 227-231.
Duff SJ, Murray WD. Bioconversion of forest products industry waste cellulosics to fuel ethanol: a review. Bioresour Technol. 1996; 55: 1-33.

Kashyap P, Sabu A, Pandey A, Szakacs G. Extracellular Lglutaminase production by Zygosaccharomyces rouxii under solidstate fermentation. Process Biochem. 2002; 38: 307-312

Kaur J, Chadha BS, Kumar BA, Saini HS. Purification and characterization of two endoglucanases from Melanocarpus sp. MTCC 3922. Biores Technol. 2007;98: 74-81

Kristo E, Biliaderis CG, Tzanetakis N. Modelling of the acidification process and rheological properties of milk fermented with a yogurt starter culture using response surface methodology. Food Chem. 2003; 83: 437-446.

Krootdilaganandh J. Isolation and selection of thermotolerant bacteria capable of producing cellulase. Chiang Mai: Chiang Mai University Press. 2000;88: 20-21.

Lee SL, Chen WC. Optimization of medium composition for the production of glucosyltransferase by Aspergillus niger with response surface methodology. Enzyme Microb Technol. 1997; 21: 436-440.

Mandels M. Applications of cellulases. Biochem Soc Trans. 1985; 13: 414-416.

Miller GL. Use of dinitrosalicylic acid regent for determination of reducing sugar. Anal Chem. 1959; 31: 426- 428. 
Nieves RA, Ehrman CL, Adney WS, Elander RT, Himmel ME. Technical communication: survey and analysis of commercial cellulase preparations suitable for biomass conversion to ethanol. W J Microbiol Biotechnol. 1998; 14: 301-304.

Ramachandran S, Patel AK, Nampoothiri KM, Francis F , Nagy V, Szakacs G, Pandey A. Coconut oil cake-a potential raw material for the production of amylase. Biores Technol. 2004; 93: 169-174.

Reczey K, Szengyel Z, Eklund R, Zacchi G. Cellulase production by T. reesei. Biores Technol. 1996; 57: 25-30.

Seiboth B, Lukas H, Salovuori N, Karin L, Robson DG, Vehmaanpera J, Penttila ME, Kubicek CP. Role of the bgal-encoded extracellular galactosidase of Hypocrea jecorina in cellulase induction by lactose. Appl Environ Microbiol. 2005 ;71:851-857.
Silva CJ, Roberto C. Optimization of xylitol production by Candida guilliermondii FTI 20037 using response surface methodology. Process Biochem. 2001; 36: 1119-1124.

Teruel MLA, Gontier E, Bienaime C, Saucedo JE, Barbotin JN. Response surface analysis of chlortetracycline and tetracycline production with Kcarrageenan mmobilized Streptomyces aureofaciens. Enzyme Microb Technol. 1997; 21: 314-320.

Wejse PL, Ingvorsen K, Mortensen KK. Xylanase production by a novel halophilic bacterium increased 20-fold by response surface methodology. Enz Microb Technol. 2003; 32: 721-727.
Received: February 26, 2011; Revised: August 28, 2011; Accepted: March 05, 2012. 